\title{
An Input-Output Analysis with an Environmentally Adjusted Agricultural and Forestry Sector in Bangladesh
}

\author{
Shamim Shakur (Corresponding author) \\ School of Economics and Finance, Social Science Tower, Room 4.22 \\ College of Business, Massey University \\ Palmerston North, New Zealand \\ E-mail: s.shakur@massey.ac.nz
}

A. K. Enamul Haque

Department of Economics, United International University

Dhaka 1209, Bangladesh

E-mail: akehaque@uiu.ac.bd

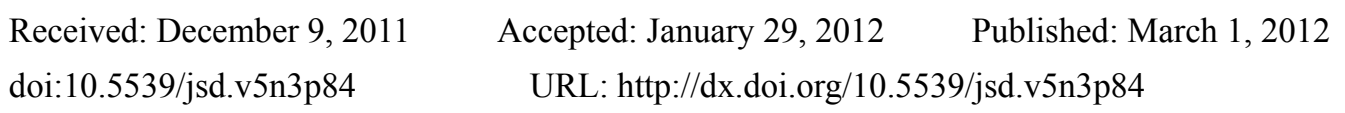

\begin{abstract}
Traditional national income accounting methods does not make an allowance for the environmental damages incurred while producing the current output. Agriculture is no longer considered to be an environmentally friendly activity. In Bangladesh, efforts to feed an ever-increasing population have meant unsustainable farming practices and a steady depletion of the resource base. The quality of the environment has been degraded and ability of the future generations compromised. This calls for "greening" of GDP by deducting negative changes in environmental quality in national income calculation. This paper begins by developing an environmental account for Bangladesh's agricultural sector. This is done by collecting physical data on depletion and degradation of environmental resources and then estimating their costs by appropriate valuation techniques. The environmentally adjusted agricultural sector is then integrated with a Social Accounting Matrix. Finally, sectoral products for agriculture and forestry are estimated net of environmental cost.
\end{abstract}

Keywords: Social accounting matrix, Input-output table, GDP, Sustainability

\section{Introduction}

The effect of the "green revolution" in Bangladesh has been mixed. Introduction of high yielding varieties (HYV) of rice and associated technology is credited with feeding an ever-expanding population of Bangladesh. The environmental damages done in the process has been formidable, and will probably carry in to the future. Alauddin and Tisdell (1989) noted a 50 to 200 per cent higher return on capital compared to labor encouraged an inappropriate choice of inputs like chemical fertilizers and modern irrigation methods over Bangladesh's much abundant labor. Higher doses of chemical fertilizers are responsible for creating conditions where the natural nutrients of the soil are fast depleting.

Very recently Goldar et al. (2011) used the input-output (I-O) methodology on 2003-04 data in order to take into account both direct and indirect emissions from the foreign trade sector of India. Certain categories of traditional export items such as cotton textiles were found to be far more damaging to the environment in this I-O framework than what their direct emission coefficient would suggest. Their recommendation to policymakers was to emphasize or de-emphasize the export of certain categories of exports in line with national environmental goals.

Our research presented in this paper forms one of the early attempts to integrating environmental accounts into national accounts. We used the economic I-O matrix to develop a social accounting matrix (SAM) for the Bangladesh economy. We then extended the analysis in the satellite account to determine the depletion and degradation impact on Gross Domestic Product (GDP). Being an early attempt, this research is confined only to the study for agriculture and forestry sector (contributed about 16.03\% of the total GDP in 2008-09) to illustrate 
that a sustainable income growth would mean a choice between sectors. If a sector has a higher degradation and depletion effect compared to other sector, then income growth using this particular sector may not be the right choice of an economy. Unlike Goldar et al. (2011) study that considered only foreign trade sector of India, our study concentrates only on two of the environmentally sensitive sectors within the domestic economy of Bangladesh.

The research is conducted in three stages: (i) to start from a suitable I-O table for the Bangladesh economy, (ii) to extend the I-O table into a Social Accounting Matrix (SAM), and finally (iii) to determine the depletion and degradation impact from agriculture and forestry activities on GDP. The SAM is a matrix presentation of the System of National Accounts (SNA) elaborating the linkages between the supply and use table, commonly known as the input-output (I-O table) and institutional sector accounts.

An adjustment to GDP from environmental damage is done by deducting environmental costs caused by economic activities including environmental degradation cost and ecological damage cost. The resultant product is an Environmentally Adjusted Domestic Product (EDP), known popularly also as "green GDP". The idea of green GDP has gained in popularity ever since the Rio Earth Summit in 1992. It is a measure of how a country is prepared for sustainable economic development. It should be noted here that the estimates presented in this research is not quantitatively at par with the green GDP accounting rules as we only include agriculture and forestry sectors for illustrative purposes. Nevertheless one can appreciate the enormity of the issues involved and a clearly defined methodology presented here to tackle a complex problem that need to be resolved.

\section{Framework for National and Input-Output Accounts}

\subsection{System of National Accounts}

In its efforts to increase comparability of economic statistics, the United Nations (1953) first published the System of National Accounts (SNA) in 1953. Initially, the SNA was comprised of six standard accounts, based on an underlying structure of production, appropriation, capital reconciliation, external transactions, and government. By now, the SNA describes a coherent, consistent and integrated set of macroeconomic accounts in the context of a set of internationally agreed concepts, definitions, classifications and accounting rules. In addition, the SNA provides an overview of economic processes, recording how production is distributed among consumers, businesses, government and foreign nations. In 1993, in response to United Nations (UN) Rio Summit, the SNA included system for integrated environmental and Economic Accounting (SEEA) to deal with the environmental issues (United Nations, 1993). In subsequent publication (United Nations, 2003) the UN conceded that methodological problems about green GDP remained unresolved and questioned even usefulness of such measure. At present the SEEA remains a satellite system, not integrated into SNA. Besides information about economic activities, the SNA now shows the levels of an economy's productive assets and the wealth of its inhabitants at particular points in time.

At a country level, China was the first country to publish its green GDP data for the year 2004, in 2006 (SEPA 2006). It showed that the financial loss caused by pollution was 511.8 billion yuan ( $\$ 66.3$ billion), or 3.05 percent of the nation's economy. It was considered a very promising development in the adoption of green GDP that proposes to discount GDP for the environmental costs lost to growing that GDP (He, 2009; Li \& Lang, 2010). In the face of mounting evidence that environmental damage and resource depletion was far more costly than anticipated, the Chinese government subsequently withdrew its support for the green GDP methodology and suppressed the 2005 report that was due to be released in 2007. Instead, the government plans to release green GDP data from 2015 in its bid to bring environmental concerns into mainstream growth accounting.

\subsection{Input-Output (I-O) Accounts}

An input-output model reflects the precise quantitative sectoral relations in an economy. Originally developed by Wassily Leontief (1936) to depict inter-industry relations of an economy, the input-output table has become an indispensable tool in any quantitative exercise. It shows how the output of one industry is an input to each other industry. It also provides a detailed analysis of the process of production and the use of goods and services (products) and the income generated from the production process. Transactions of goods and services are broken down by intermediate and final use. A complete I-O table also shows the cost structure of production activities: intermediate inputs, compensation to labour and capital, taxes on production. Later, Leontief modified the input-output model to study environmental issues relating to pollution (Leontief, 1970) (Note 1).

An I-O table is normally displayed in the form of a matrix. A given input is typically enumerated in the column of an industry and its outputs are enumerated in its corresponding row. This format, therefore, shows how dependent each industry is on all others in the economy both as customer of their outputs and as supplier of their 
inputs. Each column of the input-output matrix reports the monetary value of an industry's inputs and each row represents the value of an industry's outputs.

Table 1 illustrates a general structure of an I-O table, according to the European System of Integrated Economic Accounts (EUROSTAT, 1986).

In the standard EUROSTAT framework, Matrix A represents an intermediate demand. Rows in the matrix A describe production sector outputs. Columns represent sectors that use outputs of production as intermediate inputs. A breakdown of a final demand on private consumption, government consumption, investment, and export is shown in Matrix B. Matrix C gives the information on total domestic production. Matrices D, E and F give the corresponding information on imported goods and services. Payments to labour and capital, depreciation, and indirect taxes are presented in Matrix G. Matrix H is normally empty, and summation over rows in Matrix I gives information on value-added. If an I-O table is balanced, then columns of Matrix $\mathrm{J}$ should be the same as the rows of Matrix $\mathrm{C}$ because total input equals total output for production sectors.

For Bangladesh, a condensed I-O table corresponding only to intermediate demands (Matrix A as per Table 1) for the economy is shown in Table 2. The Bangladesh Institute of Development Studies (BIDS, 1998) constructed a 1993-94 I-O table (Note 2). The current I-O table is an up-dated version of the BIDS (1998) estimate using 1998-99 national accounts data. The BIDS (1998) I-O Table was constructed with 79 sectors. A complete listing of these component sectors is provided in Appendix 1, which shows a relatively well-documented, I-O data in as far as for the agricultural sector is concerned.

Admittedly the data used in this research are dated, but release of new I-O data can take up to a decade and are usually comes incomplete initially. For Bangladesh, a newer I-O table was constructed by researchers at Dhaka University and the Bangladesh Institute of Development Studies (BIDS) in 2006-07. There were number of gaps reported in this newer I-O table. For example, a high number of cells across the rows and columns were empty (GHK, 2010). An operational version of the original table was constructed by merging a number of sectors while splitting other sectors that was less than robust. The I-O table used in this study does not have similar shortcomings and represents a better choice in our judgment.

The base year used for the I-O Table 2 is 1998-99, the latest period in which complete national accounts data was available from Bangladesh Bureau of Statistics. The 17x17 use matrix reported forms the core of the I-O table. The I-O coefficients have been used to split out the production value of the various commodities as found in the national statistics. The sectoral GDP column describes the value of outputs by sectors. The total sum of the cells in the column matrix equals the total domestic production of the Bangladesh economy.

The I-O table shows only the relationship between production accounts. Thus, an entry in a cell $\mathrm{a}_{\mathrm{ij}}$ tells the proportion of sector i's output used in the production of a sector $\mathrm{j}$. The use matrix also contains a large number of cells with zero entries. This is because many activities take inputs only from some sectors and not from all sectors. Agriculture and forestry, for example, cannot be expected to use hotels and restaurants as an intermediary input. The crop sector has been aggregated over 15 major crops (paddy, wheat, sugarcane, etc.), while livestock, forestry and fishing (including shrimp farming) has been kept separate (refer to Appendix 1).

\section{Social Accounting Matrix (SAM)}

A SAM is an expanded version of an I-O table that is designed to capture specific details of various economic flows in a matrix format. Traditionally applied to analyze causes and consequences of various aspects of inequality among household groups, an extended SAM is currently used as a conceptual and modular framework for policy and planning purposes. A detailed SAM integrates the four existing economic frameworks in the country: (i) System of National Accounts, (ii) Balance of Payments, (iii) Flow-of-Funds, and (iv) Input-Output Table. The SAM, therefore, provides a comprehensive quantified description of the macro-economic and financial interrelationships in the country. A more detailed discussion on the construction and uses of SAM can be found in Pyatt and Round (1985). For our purposes, SAM can provide useful information about intersectoral linkages, including the one's that exist between agriculture and environment, the focus of this research. Table 3 shows the SAM matrix for Bangladesh for the year 1998-99. The SAM is based on the 1998-99 I-O Table as reported in Table 2.

For compactness, we have aggregated 79 sectors from BIDS (1998) 1993-94 I-O table to form a 17x17 SAM. The 79 sectors were originally chosen in BIDS (1998) project on the basis of the importance of the sectors and commodities (paddy, jute, livestock, forestry, RMG, etc.) to reflect, as best as possible, the structure of the Bangladesh economy. 18 agricultural products have been aggregated as "crop" sector while 38 industrial outputs have been aggregated as "manufacturing" sector. Other aggregations done are shown in Appendix 1 (Note 3). 
Like the I-O Table 2, The SAM, as calculated here, incorporates only the production side, (the input-output table), while the distribution and transfers among various institutions (households, enterprises and government) are ignored. Flexibility of SAM allows division of the sectors into different sub-sectors and in taking account of the transactions among them (i.e. among different sectors and within the sub-sectors). The primary sector, for example, has been disaggregated into crop, livestock, forest, fishing and mining, and the table could be used to trace the environmental effect of a specific production shift among various sub-sectors.

Let us take a closer look at Table 3 to see its correspondence with I-O table (Table 2). Rows in table 3 represent production sector outputs, which are used as intermediate inputs for other sectors. Columns in Table 3 represent intermediate consumers (production sectors which use an output of production sectors as intermediate inputs). Looking along a particular column of Table 3, one can see how inputs are used for production in a certain sector. Take for example row 2, livestock. We can see, from column 1, that the crop sector has consumed a livestock output in the value of 16,144, while the third column shows that the forest sector as an insignificant consumer of livestock. Finally, there is a relationship between an I-O table and Gross Domestic Product (GDP). Sectoral GDP can be calculated as sum of the columns corresponding to a sector. This is reported in the last column of Table 3 . By summing up the entries in this column, we can obtain the GDP figures. GDP is defined as the value of final goods and services produced in a given year. Hence, alternatively, we can extract information on GDP from an I-O table by eliminating intermediate production - goods that are used up to produce other goods.

\section{Discussion of Results}

For Bangladesh, SAM has been developed using the input-output (I-O) table (Table 2) for the economy and this is shown in Table 3. Based on these I-O and SAM tables and by incorporating in them the information on forestry acreage, deforestation rate, cultivable land under rice cultivation, we calculated the depletion and degradation impact on the national economy.

Using the SAM matrix, Table 4 then shows the division of agricultural output for use as intermediate goods and as final demand. A negative entry in this table would mean this sector has a net import.

Forestry and agricultural activities generate methane and ammonia emission - both are greenhouse gases. In addition, water and land emissions from agriculture include run-off pesticides and soil nutrients. Due to lack of information on valuation, we did not include these in our environmentally adjusted GDP calculations. However, agricultural and forestry activities also causes soil erosion and loss of opportunities for the communities to use forest products. These two impacts are estimated during period 1998-99 using secondary information and reported in Table 5.

Finally, based on the above, we have estimated the gross and net (of environmental cost) sectoral product for agriculture and forestry. These are presented in Figure 1 and Figure 2. Figure 1 shows that due to erosion, agricultural sector lost a sizeable output. This is nearly 2 percent of the sectoral product (see Table 5). Figure 2 then shows the product of the forestry sector and the adjusted product. It is evident that deforestation (a type of depletion) has reduced the forestry sector output by nearly 50 percent. The losses are calculated in terms of depletion of forest product and soil erosion due to deforestation. The last diagram, Figure 3, shows the percent loss in GDP if we adjust it for degradation and depletion.

\section{Concluding Observations}

From the results obtained in this research, it is clear that had there been a choice, utilization of renewable resources without causing depletion is a better choice. Estimates of rather large deforestation impact in this research suggest that attempts to raise GDP using forestry sector is not environmentally sustainable.

The presentation above has shown that to make an optimum decision for the society, traditional gross domestic product (GDP) does not provide a long-term perspective. Consideration of net losses of natural resources and environmental assets would imply Bangladesh's GDP need to be reduced significantly, especially if manufacturing and service sectors are considered. The current research was restricted to a narrow set of damages from agricultural and forestry sectors and it is only logical to extend the analysis to all sectors. This suggests that it is the (environmentally adjusted) ecological domestic product (EDP) that needs to be used to ensure a sustainable development.

\section{References}

Alaudddin, M., \& Tisdell, C. A. (1998). The Environment and Economic Development in South Asia: An Overview Concentrating on Bangladesh Macmillan Press Ltd., United Kingdom.

Bangladesh Institute of Development Studies. (1998). An Input-Output Table for the Bangladesh Economy, 
1993-94, BIDS, Dhaka, Bangladesh.

EUROSTAT. (2008). Eurostat Manual of Supply, Use and Input-Output Tables, EUROSTAT, Luxembourg, Luxembourg (2008).

GHK. (2010). Estimating green jobs in Bangladesh, A report prepared by GHK Consulting Limited for the International Labour Organisation, June 2010. 94 pages.

Goldar, A., Bhanot, J., \& Shimpoc, K. (2011). Prioritizing towards a green export portfolio for India: An environmental input-output approach. Energy Policy, 39 (11), 7036-7048. http://dx.doi.org/10.1016/j.enpol.2011.08.008

He, F. (2009). Price of prosperity: economic development and biological conservation in China. Journal of Applied Ecology, 46 (3), 511-515. http://dx.doi.org/10.1111/j.1365-2664.2009.01641.x

Leontief, W. W. (1936). Quantitative Input-Output Relations in the Economic System of the United States. Review of Economics and Statistics, XVIII, 105-25. http://dx.doi.org/10.2307/1927837

Leontief, W. W. (1970). Environmental Repercussions and Economic Structure: An Input-Output Approach. Review of Economics and Statistics, 52 (3), 262-271. http://dx.doi.org/10.2307/1926294

Li. V., \& Lang, G. (2010). China's "Green GDP" Experiment and the Struggle for Ecological Modernisation. Journal of Contemporary Asia, 40 (1), 44-62. http://dx.doi.org/10.1080/00472330903270346

Pyatt, G., \& Round, J. I. (Ed.) (1985). Social Accounting Matrices: A Basis for Planning. The World Bank, Washington, D. C.

SEEA. (2003). Handbook of National Accounting, Integrated Environmental and Economic Accounting, New York: United Nations, European Commission, International Monetary Fund, Organization for Economic Co-operation and Development, World Bank.

SEPA. (2006). China Green GDP Accounting Study Report 2004. State Environmental Protection Administration (the Chinese Academy for Environmental Planning), Beijing.

United Nations. (1953). A System of National Accounts and Supporting Tables, Studies in Methods, Series F, No. 2, New York.

United Nations. (1993). Handbook of National Accounting: Integrated Environmental and Economic accounting, Interim Version, United Nations (ST/ESA/STAT/SER.F/61).

United Nations. (2003). Integrated Environmental and Economic Accounting: Final Draft Circulated for Information Prior to Official Editing, New York: United Nations.

\section{Notes}

Note 1. Wassily Leontief received the 1973 Nobel Prize in Economics for his pioneering work in input- output method and its application to important economic problems that includes environmental issues.

Note 2. Bangladesh Planning Commission and Bangladesh Institute of Development Studies. 1998. An Input-Output Table for Bangladesh Economy, 1993-94. Dhaka, Bangladesh.

Note 3. Same aggregation also done in constructing an aggregated I-O table, which is presented in Table 2. 
Table 1. General structure of an input-output table

\begin{tabular}{|c|c|c|c|c|c|c|c|c|c|c|}
\hline & & \multirow{2}{*}{\multicolumn{4}{|c|}{$\begin{array}{l}\text { INTERMEDIATE USE } \\
\text { By Production Sectors }\end{array}$}} & \multicolumn{4}{|c|}{ FINAL USE } & \multirow{3}{*}{ Output } \\
\hline & & & & & & \multirow{2}{*}{$\begin{array}{c}\text { Private } \\
\text { Consum } \\
\text { p. }\end{array}$} & \multirow{2}{*}{$\begin{array}{c}\text { Gov't } \\
\text { Consum } \\
\text { p. }\end{array}$} & \multirow[b]{2}{*}{ Invest. } & \multirow[b]{2}{*}{ Export } & \\
\hline & & 1 & 2 & $\ldots \mathrm{j} \ldots$ & $\mathrm{n}$ & & & & & \\
\hline & 1 & & & & & & & & & \\
\hline Domestic & 2 & & & & & & & & & \\
\hline \multicolumn{11}{|l|}{ Production } \\
\hline & $\mathrm{i}$ & & & A & & & $\mathrm{B}$ & & & $\mathrm{C}$ \\
\hline & $:$ & & & & & & & & & \\
\hline & $\mathrm{n}$ & & & & & & & & & \\
\hline & 1 & & & & & & & & & \\
\hline & 2 & & & & & & & & & \\
\hline \multicolumn{11}{|l|}{ Imports } \\
\hline & $\mathrm{i}$ & & & $\mathrm{D}$ & & & $\mathrm{E}$ & & & $\mathrm{F}$ \\
\hline & $\cdot$ & & & & & & & & & \\
\hline & $\mathrm{n}$ & & & & & & & & & \\
\hline \multicolumn{11}{|l|}{ Value added: } \\
\hline \multicolumn{11}{|l|}{-labor } \\
\hline -capital & & & & $\mathrm{G}$ & & & $\mathrm{H}$ & & & $\mathrm{I}$ \\
\hline \multicolumn{11}{|l|}{-indirect } \\
\hline \multicolumn{11}{|l|}{ taxes } \\
\hline INPUT & & & & $\mathrm{J}$ & & & & & & \\
\hline
\end{tabular}

Source: EUROSTAT, 1986

Table 2. A condensed input-output table of Bangladesh

\begin{tabular}{|c|c|c|c|c|c|c|c|c|c|c|c|c|c|c|c|c|c|}
\hline Sector & 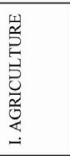 & 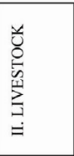 & 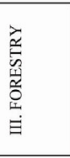 & 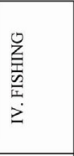 & 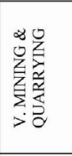 & 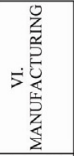 & 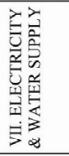 & 方芯 & 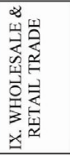 & 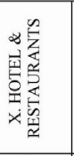 & 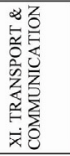 & 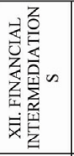 & 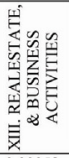 & 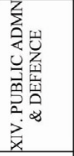 & 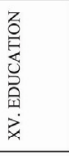 & 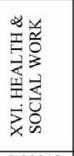 & 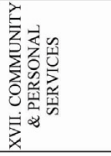 \\
\hline I. AGRICULTURE & $\begin{array}{c}0.08488 \\
845\end{array}$ & $\begin{array}{c}0.17716 \\
6143\end{array}$ & 0 & 0 & 0 & $\begin{array}{c}0.27704 \\
6805\end{array}$ & 0 & 0 & 0 & $\begin{array}{c}0.09678 \\
3813\end{array}$ & 0 & 0 & $\begin{array}{c}0.00058 \\
064\end{array}$ & 0 & 0 & $\begin{array}{c}0.00018 \\
066\end{array}$ & 0.001869459 \\
\hline II. LIVESTOCK & $\begin{array}{c}0.08332 \\
2115\end{array}$ & $\begin{array}{c}0.01769 \\
3436\end{array}$ & $\begin{array}{c}5.25539 \\
\mathrm{E}-06\end{array}$ & $\begin{array}{c}0.00313 \\
2601\end{array}$ & 0 & $\begin{array}{c}0.01338 \\
598\end{array}$ & 0 & 0 & 0 & $\begin{array}{c}0.18086 \\
6957\end{array}$ & 0 & 0 & 0 & 0 & 0 & $\begin{array}{c}0.00079 \\
8958\end{array}$ & 0 \\
\hline III. FORESTRY & $\begin{array}{c}0.00270 \\
6653\end{array}$ & 0 & $\begin{array}{c}6.3191 \\
\mathrm{E}-09 \\
\end{array}$ & $\begin{array}{c}0.00122 \\
8501\end{array}$ & 0 & $\begin{array}{c}0.00718 \\
0095\end{array}$ & 0 & $\begin{array}{c}0.01328 \\
0206\end{array}$ & 0 & 0 & 0 & 0 & $\begin{array}{c}0.12366 \\
5283\end{array}$ & 0 & 0 & 0 & 0 \\
\hline IV. FISHING & 0 & $\begin{array}{c}0.00118 \\
3526\end{array}$ & 0 & $\begin{array}{c}0.04430 \\
0715\end{array}$ & 0 & $\begin{array}{c}0.01319 \\
5834\end{array}$ & 0 & 0 & 0 & $\begin{array}{c}0.07555 \\
4117\end{array}$ & 0 & 0 & 0 & 0 & 0 & $\begin{array}{c}0.00012 \\
4671\end{array}$ & 0 \\
\hline $\begin{array}{l}\text { V.MINING \& } \\
\text { QUARRYING }\end{array}$ & 0 & 0 & 0 & 0 & 0 & $\begin{array}{c}0.00624 \\
6768\end{array}$ & 0 & $\begin{array}{c}0.08263 \\
7309\end{array}$ & 0 & 0 & 0 & 0 & $\begin{array}{c}0.01078 \\
8164\end{array}$ & 0 & 0 & 0 & 0 \\
\hline VI. MANUFACTURING & $\begin{array}{c}0.09733 \\
9263\end{array}$ & $\begin{array}{c}0.17870 \\
8261\end{array}$ & $\begin{array}{c}0.00168 \\
1733\end{array}$ & $\begin{array}{c}0.17870 \\
8261\end{array}$ & \begin{tabular}{|c|}
0.01258 \\
1913 \\
\end{tabular} & $\begin{array}{c}0.30912 \\
2219\end{array}$ & $\begin{array}{c}0.09832 \\
3019\end{array}$ & $\begin{array}{c}0.46738 \\
7849\end{array}$ & $\begin{array}{c}0.10025 \\
7428\end{array}$ & $\begin{array}{c}0.21389 \\
3459\end{array}$ & $\begin{array}{c}0.16317 \\
8769\end{array}$ & $\begin{array}{c}0.03545 \\
1707\end{array}$ & $\begin{array}{c}0.23958 \\
6035\end{array}$ & $\begin{array}{c}0.09379 \\
5111\end{array}$ & $\begin{array}{c}0.08879 \\
2185\end{array}$ & $\begin{array}{c}0.01635 \\
7333\end{array}$ & 0.096040566 \\
\hline $\begin{array}{l}\text { VII. ELECTRICITY \& } \\
\text { WATER SUPPLY }\end{array}$ & $\begin{array}{c}0.00198 \\
0006\end{array}$ & $\begin{array}{c}0.00199 \\
5425\end{array}$ & 0 & 0 & $\begin{array}{c}0.00024 \\
8518\end{array}$ & $\begin{array}{c}0.02875 \\
4305\end{array}$ & $\begin{array}{l}0.09914 \\
8411\end{array}$ & $\begin{array}{c}0.00091 \\
1414\end{array}$ & $\begin{array}{c}0.01173 \\
063\end{array}$ & $\begin{array}{l}0.03736 \\
9171\end{array}$ & $\begin{array}{l}0.00090 \\
2863\end{array}$ & $\begin{array}{l}0.00808 \\
2897\end{array}$ & $\begin{array}{c}0.00037 \\
0361\end{array}$ & $\begin{array}{c}0.01035 \\
3909\end{array}$ & $\begin{array}{c}0.01871 \\
4529\end{array}$ & $\begin{array}{c}0.00129 \\
9629\end{array}$ & 0.005097207 \\
\hline VIII. CONTRUCTION & $\begin{array}{c}0.00155 \\
4773\end{array}$ & 0 & $\begin{array}{c}1.73207 \\
\mathrm{E}-05\end{array}$ & 0 & \begin{tabular}{|c|}
9.05492 \\
$\mathrm{E}-05$ \\
\end{tabular} & $\begin{array}{c}9.09671 \\
\mathrm{E}-06 \\
\end{array}$ & $\begin{array}{c}0.00472 \\
8821\end{array}$ & $\begin{array}{c}0.00308 \\
2681 \\
\end{array}$ & 0 & 0 & $\begin{array}{c}0.00025 \\
9535\end{array}$ & 0 & 0 & 0 & 0 & 0 & 0 \\
\hline $\begin{array}{l}\text { IX. WHOLESALE \& } \\
\text { RETAIL TRADE }\end{array}$ & $\begin{array}{c}0.13755 \\
6849\end{array}$ & $\begin{array}{c}0.05500 \\
6827\end{array}$ & $\begin{array}{c}0.06825 \\
1756\end{array}$ & $\begin{array}{c}0.37135 \\
0981\end{array}$ & $\begin{array}{c}0.30730 \\
2401\end{array}$ & $\begin{array}{c}0.05324 \\
7865\end{array}$ & $\begin{array}{c}0.05179 \\
3437\end{array}$ & $\begin{array}{c}0.04264 \\
0066\end{array}$ & 0 & $\begin{array}{c}0.04807 \\
5482\end{array}$ & $\begin{array}{c}0.09352 \\
148\end{array}$ & $\begin{array}{c}0.22535 \\
8392\end{array}$ & $\begin{array}{c}0.05561 \\
7825\end{array}$ & 0 & $\begin{array}{c}0.12708 \\
1166\end{array}$ & $\begin{array}{c}0.16125 \\
839\end{array}$ & 0.077313286 \\
\hline $\begin{array}{c}\text { X. HOTEL \& } \\
\text { RESTAURANTS }\end{array}$ & 0 & 0 & 0 & 0 & 0 & $\begin{array}{c}.49729 \\
\mathrm{E}-05\end{array}$ & 0 & 0 & 0 & 0 & $\begin{array}{l}0.00164 \\
209\end{array}$ & $\begin{array}{c}0.01478 \\
7472\end{array}$ & 0 & $\begin{array}{c}0.00386 \\
9912 \\
\end{array}$ & $\begin{array}{l}0.00277 \\
7086\end{array}$ & 0 & 0 \\
\hline $\begin{array}{l}\text { XI. TRANSPORT \& } \\
\text { COMMUNICATION }\end{array}$ & $\begin{array}{c}0.03829 \\
2859\end{array}$ & $\begin{array}{l}0.04557 \\
9901\end{array}$ & $\begin{array}{l}0.01002 \\
2747\end{array}$ & $\begin{array}{c}0.01115 \\
4897\end{array}$ & $\begin{array}{l}0.17277 \\
7755\end{array}$ & $\begin{array}{c}0.02684 \\
064\end{array}$ & $\begin{array}{c}0.00380 \\
8588\end{array}$ & $\begin{array}{c}0.04298 \\
4022\end{array}$ & $\begin{array}{c}0.02840 \\
4746\end{array}$ & $\begin{array}{l}0.00872 \\
5949\end{array}$ & $\begin{array}{l}0.04046 \\
7204\end{array}$ & $\begin{array}{c}0.03424 \\
1897\end{array}$ & $\begin{array}{l}0.03848 \\
9847\end{array}$ & $\begin{array}{l}0.07149 \\
9513\end{array}$ & $\begin{array}{c}0.01457 \\
0821\end{array}$ & $\begin{array}{l}0.00104 \\
3841\end{array}$ & 0.083050215 \\
\hline $\begin{array}{c}\text { XII. FINANCIAL } \\
\text { INTERMEDIATIONS }\end{array}$ & $\begin{array}{l}0.00052 \\
2028\end{array}$ & $\begin{array}{c}0.00015 \\
9303\end{array}$ & $\begin{array}{c}3.4924 \\
\mathrm{E}-06\end{array}$ & $\begin{array}{l}0.00038 \\
7192\end{array}$ & $\begin{array}{c}8.61202 \\
\mathrm{E}-05\end{array}$ & $\begin{array}{c}0.01292 \\
8375\end{array}$ & $\begin{array}{c}0.00041 \\
7866\end{array}$ & 0 & $\begin{array}{c}0.02417 \\
504\end{array}$ & 0 & $\begin{array}{c}0.00081 \\
5003\end{array}$ & $\begin{array}{c}0.00233 \\
6275\end{array}$ & $\begin{array}{c}.36549 \\
\mathrm{E}-05\end{array}$ & 0 & 0 & $\begin{array}{c}0.01679 \\
4998\end{array}$ & 0 \\
\hline $\begin{array}{c}\text { XIII. REALESTATE \& } \\
\text { BUSINESS ACTIVITIES }\end{array}$ & 0 & 0 & 0 & 0 & 0 & $\begin{array}{c}0.02527 \\
8262\end{array}$ & 0 & 0 & $\begin{array}{c}0.00268 \\
1463\end{array}$ & 0 & $\begin{array}{c}0.00011 \\
4984\end{array}$ & $\begin{array}{c}0.00763 \\
8311\end{array}$ & 0 & $\begin{array}{c}0.09897 \\
9358\end{array}$ & $\begin{array}{c}0.01366 \\
8776\end{array}$ & $\begin{array}{l}0.07608 \\
5004\end{array}$ & 0 \\
\hline $\begin{array}{l}\text { XIV. PUBLIC ADMN \& } \\
\text { DEFENCE }\end{array}$ & $\begin{array}{c}0.00063 \\
4874\end{array}$ & $\begin{array}{c}0.00027 \\
302\end{array}$ & $\begin{array}{c}0.00159 \\
0936\end{array}$ & $\begin{array}{c}0.00029 \\
7017\end{array}$ & $\begin{array}{c}0.00120 \\
5683\end{array}$ & $\begin{array}{c}0.00145 \\
8439\end{array}$ & $\begin{array}{c}0.00254 \\
3054\end{array}$ & $\begin{array}{c}0.01868 \\
1898\end{array}$ & $\begin{array}{c}0.01601 \\
0387\end{array}$ & $\begin{array}{c}0.00837 \\
3438\end{array}$ & $\begin{array}{l}0.01326 \\
2705\end{array}$ & $\begin{array}{c}0.00016 \\
042\end{array}$ & 0 & $\begin{array}{c}0.02563 \\
5209\end{array}$ & $\begin{array}{c}0.02166 \\
5941\end{array}$ & $\begin{array}{c}0.00079 \\
8994\end{array}$ & 0.001178427 \\
\hline XV. EDUCATION & 0 & 0 & 0 & 0 & 0 & $\begin{array}{c}6.56427 \\
\mathrm{E}-05 \\
\end{array}$ & 0 & 0 & 0 & 0 & 0 & 0 & 0 & 0 & 0 & 0 & 0 \\
\hline $\begin{array}{c}\text { XVI. HEALTH \& SOCIAL } \\
\text { WORK }\end{array}$ & 0 & $\begin{array}{c}0.01355 \\
4841\end{array}$ & 0 & $\begin{array}{c}0.00143 \\
7187\end{array}$ & 0 & $\begin{array}{c}0.00018 \\
8008\end{array}$ & 0 & 0 & $\begin{array}{c}0.04643 \\
4866\end{array}$ & $\begin{array}{c}0.01964 \\
539\end{array}$ & $\begin{array}{c}0.00313 \\
9023\end{array}$ & 0 & 0 & $\begin{array}{c}0.00037 \\
6603\end{array}$ & $\begin{array}{l}0.00057 \\
2894\end{array}$ & $\begin{array}{c}0.00448 \\
5954\end{array}$ & 0.035037394 \\
\hline $\begin{array}{l}\text { XVII. COMMUNITY \& } \\
\text { PERSONAL SERVICES }\end{array}$ & $\begin{array}{l}0.00311 \\
9177\end{array}$ & $\begin{array}{c}0.00089 \\
9318\end{array}$ & $\begin{array}{l}6.24117 \\
\mathrm{E}-06\end{array}$ & $\begin{array}{c}0.00206 \\
0979\end{array}$ & 0 & $\begin{array}{c}0.00049 \\
4437\end{array}$ & $\begin{array}{c}0.00306 \\
4722\end{array}$ & $\begin{array}{l}0.02187 \\
7943\end{array}$ & $\begin{array}{l}0.01180 \\
0047\end{array}$ & $\begin{array}{l}0.00083 \\
7387\end{array}$ & $\begin{array}{l}0.01374 \\
793\end{array}$ & $\begin{array}{l}0.01638 \\
5596\end{array}$ & $\begin{array}{c}4.36549 \\
\mathrm{E}-05\end{array}$ & $\begin{array}{c}0.02084 \\
6867\end{array}$ & $\begin{array}{l}0.00926 \\
206\end{array}$ & $\begin{array}{c}0.00132 \\
6809\end{array}$ & 0.012338428 \\
\hline
\end{tabular}


Table 3. A condensed Social Accounting Matrix (SAM) for Bangladesh, 1998-99

\begin{tabular}{|c|c|c|c|c|c|c|c|c|c|c|c|c|c|c|c|c|c|c|}
\hline Sector & 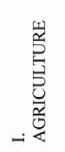 & 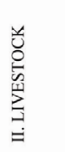 & 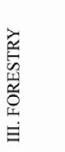 & 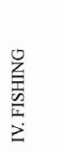 & 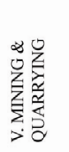 & 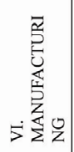 & 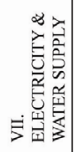 & 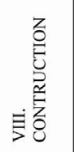 & 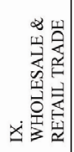 & 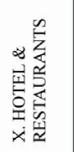 & 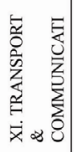 & 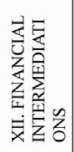 & 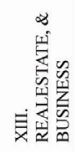 & 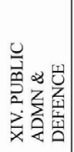 & 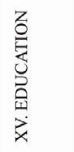 & 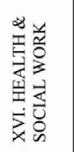 & 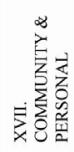 & 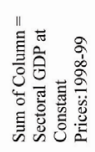 \\
\hline I. AGRICULTURE & 392. & 73,865 . & - & & - & 115,50 & - & & - & 40,352 & & - & 242.08 & - & & 75.322 & 779.43 & $266,216.00$ \\
\hline II. LIVESTOCK & 16,144 . & $3,428.3$ & 1.018 & 606.98 & - & $2,593.7$ & - & & - & 35,045 . & - & - & 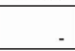 & - & - & 154.80 & - & $57,975.000$ \\
\hline III. FORESTRY & 644.52 & & 0.002 & 292.53 & - & $1,709.7$ & - & $3,162.3$ & - & & - & - & $29,447$. & - & - & - & - & $35,257.000$ \\
\hline IV. FISHING & - & 971.07 & - & 36,348 . & - & $10,827$. & - & -1 & - & $61,991$. & - & - & - & - & - & 102.29 & - & $110,240.00$ \\
\hline $\begin{array}{l}\text { V. MINING \& } \\
\text { QUARRYING }\end{array}$ & - & & - & . & - & $1,160.8$ & - & 15,356 & - & (1, & 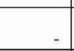 & - & $2,004.7$ & - & - & T0.25 & - & $18,522.000$ \\
\hline $\begin{array}{l}\text { VI. } \\
\text { MANUFACTURING }\end{array}$ & $11,800$. & 21,664 . & 203.87 & 21,664 . & $1,525.2$ & 37,474 & 11,919 & 56,660 & 12,154 & 25,929 & 19,781 & $4,297.7$ & 29,044 . & 11,370 & 10,764 & $1,982.9$ & 11,642 & $289,882.00$ \\
\hline $\begin{array}{l}\text { VII. ELECTRICITY } \\
\& \text { WATER SUPPLY }\end{array}$ & 0.86 & 232.66 & . & 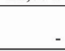 & 28.977 & $3,352.6$ & 11,560 . & 106.26 & $1,367.7$ & $4,357.1$ & 105.27 & 942.45 & 43.183 & $1,207.2$ & $2,182.0$ & 151.53 & 594.32 & $26,463.000$ \\
\hline $\begin{array}{l}\text { VIII. } \\
\text { CONTRUCTION }\end{array}$ & 22,740 . & & 253.34 & & $1,324.4$ & 133.05 & 69,166 . & 45,088 & - & & $3,796.0$ & & & & & & & $142,503.00$ \\
\hline $\begin{array}{l}\text { IX. WHOLESALE \& } \\
\text { RETAIL TRADE }\end{array}$ & $17,998$. & $7,197.1$ & $8,930.1$ & $48,588$. & $40,207$. & $6,967.0$ & $6,776.7$ & $5,579.0$ & - & $6,290.2$ & 12,236 & $29,486$. & $7,277.1$ & - & $16,627$. & 21,099 & 10,115 & $245,377.00$ \\
\hline $\begin{array}{l}\text { X. HOTEL \& } \\
\text { RESTAURANTS }\end{array}$ & - & - & - & - & - & 7.563 & - & - & - & - & 829.45 & $7,469.4$ & - & $1,954.7$ & $1,402.7$ & - & - & $11,664.000$ \\
\hline $\begin{array}{l}\text { XI. TRANSPORT \& } \\
\text { COMMUNICATION }\end{array}$ & $9,745.8$ & $11,600$. & $2,550.8$ & $2,839.0$ & 43,973 . & $6,831.1$ & 969.32 & 10,939 & $7,229.2$ & $2,220.8$ & 10,299 . & $8,714.8$ & $9,796.0$ & 18,197 . & $3,708.4$ & 265.66 & 21,137 & $171,019.00$ \\
\hline $\begin{array}{l}\text { XII. FINANCIAL } \\
\text { INTERMEDIATION }\end{array}$ & 261.28 & 79.734 & 1.748 & 193.79 & 43.105 & $6,470.8$ & 209.14 & - & $12,100$. & - & 407.92 & $1,169.3$ & 21.850 & - & - & $8,406.1$ & - & $29,365.000$ \\
\hline $\begin{array}{l}\text { XIII. REALESTATE } \\
\text { \& BUSINESS }\end{array}$ & 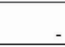 & & 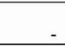 & & - & 18.980. & - & - & 2.013 .4 & - & 86.337 & 5.735 .3 & - & 74.319 . & 10,263 & $57,129$. & - & 168.528 .00 \\
\hline $\begin{array}{l}\text { XIV. PUBLIC } \\
\text { ADMN \& DEFENCE }\end{array}$ & 264.68 & 113.82 & 663.27 & 123.82 & 502.66 & 608.03 & $1,060.2$ & $7,788.6$ & $6,674.8$ & $3,490.9$ & $5,529.3$ & 66.881 & - & 10,687 . & $9,032.7$ & 333.10 & 491.29 & $47,432.000$ \\
\hline XV. EDUCATION & 20.00 & & . & & 30.00 & 40,304 &, 000.2 & , & 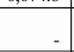 & , & 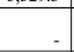 & 00.001 & - & 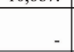 & , & (1) & - & $40,304.000$ \\
\hline $\begin{array}{l}\text { XVI. HEALTH \& } \\
\text { SOCIAL WORK }\end{array}$ & - & $4,489.7$ & - & 476.03 & - & 62.273 & - & - & 15,380 . & $6,507.0$ & $1,039.7$ & - & - & 124.74 & 189.75 & $1,485.8$ & 11,605 & $41,361.000$ \\
\hline $\begin{array}{l}\text { XVII. COMMUNITY } \\
\text { \& PERSONAL }\end{array}$ & $4,108.5$ & $1,184.5$ & 8.221 & $2,714.6$ & - & 651.26 & $4,036.8$ & 28,817 & $15,542$. & $1,102.9$ & 18,108 & 21,582 . & 57.502 & 27,459 . & 12,199 & $1,747.6$ & 16,252 & $155,575.00$ \\
\hline
\end{tabular}


Table 4. Distribution of agricultural and forestry sector output as intermediate goods and as final demand in the economy

\begin{tabular}{|c|c|c|}
\hline \multicolumn{3}{|c|}{ Intermediate Use } \\
\hline $1993-94$ & Agriculture & Forestry \\
\hline $1994-95$ & 76221.7016 & 7272.961837 \\
\hline $1995-96$ & 80032.6034 & 3892.446557 \\
\hline $1996-97$ & 83493.9782 & 19159.29465 \\
\hline $1997-98$ & 88024.803 & 21429.46513 \\
\hline $1998-99$ & 92685.9889 & 17180.30255 \\
\hline $1993-94$ & 96848.3506 & 14800.29962 \\
\hline $1994-95$ & & 22531.03816 \\
\hline $1995-96$ & 167950.298 & 26943.55344 \\
\hline $1996-97$ & 155788.397 & 12919.70535 \\
\hline $1997-98$ & 156431.022 & -214291.2987 \\
\hline $1998-99$ & 167351.197 & -171799.4998 \\
\hline
\end{tabular}

Table 5. Loss of product due to erosion and deforestation (secondary estimates)

\begin{tabular}{|c|c|c|c|c|}
\hline & $\begin{array}{l}\text { Loss from } \\
\text { Agriculture }\end{array}$ & $\begin{array}{c}\text { Loss from } \\
\text { Deforestation }\end{array}$ & Total Loss & $\begin{array}{l}\text { Percent of Sectoral } \\
\text { Product }\end{array}$ \\
\hline \multicolumn{5}{|c|}{ Soil Erosion } \\
\hline 1993-94 & 7325.16 & 110.547 & 7435.70689 & 0.01864749 \\
\hline 1994-95 & 7074.63 & 114.970 & 7189.59971 & 0.018085 \\
\hline $1995-96$ & 7197.75 & 125.755 & 7323.50477 & 0.01786735 \\
\hline 1996-97 & 7661.28 & 126.039 & 7787.31859 & 0.01792434 \\
\hline $1997-98$ & 7741.71 & 131.786 & 7873.49589 & 0.01756316 \\
\hline 1998-99 & 7986.48 & 131.786 & 8118.26589 & 0.01728438 \\
\hline \multicolumn{5}{|c|}{ Traditional use of forest resources } \\
\hline 1993-94 & & 403.3618318 & 403.361832 & 0.00101156 \\
\hline $1994-95$ & & 419.499757 & 419.499757 & 0.00105523 \\
\hline $1995-96$ & & 458.8521308 & 458.852131 & 0.00111947 \\
\hline $1996-97$ & & 459.8877196 & 459.88772 & 0.00105854 \\
\hline $1997-98$ & & 480.8583925 & 480.858393 & 0.00107264 \\
\hline 1998-99 & & 480.8583925 & 480.858393 & 0.00102378 \\
\hline
\end{tabular}




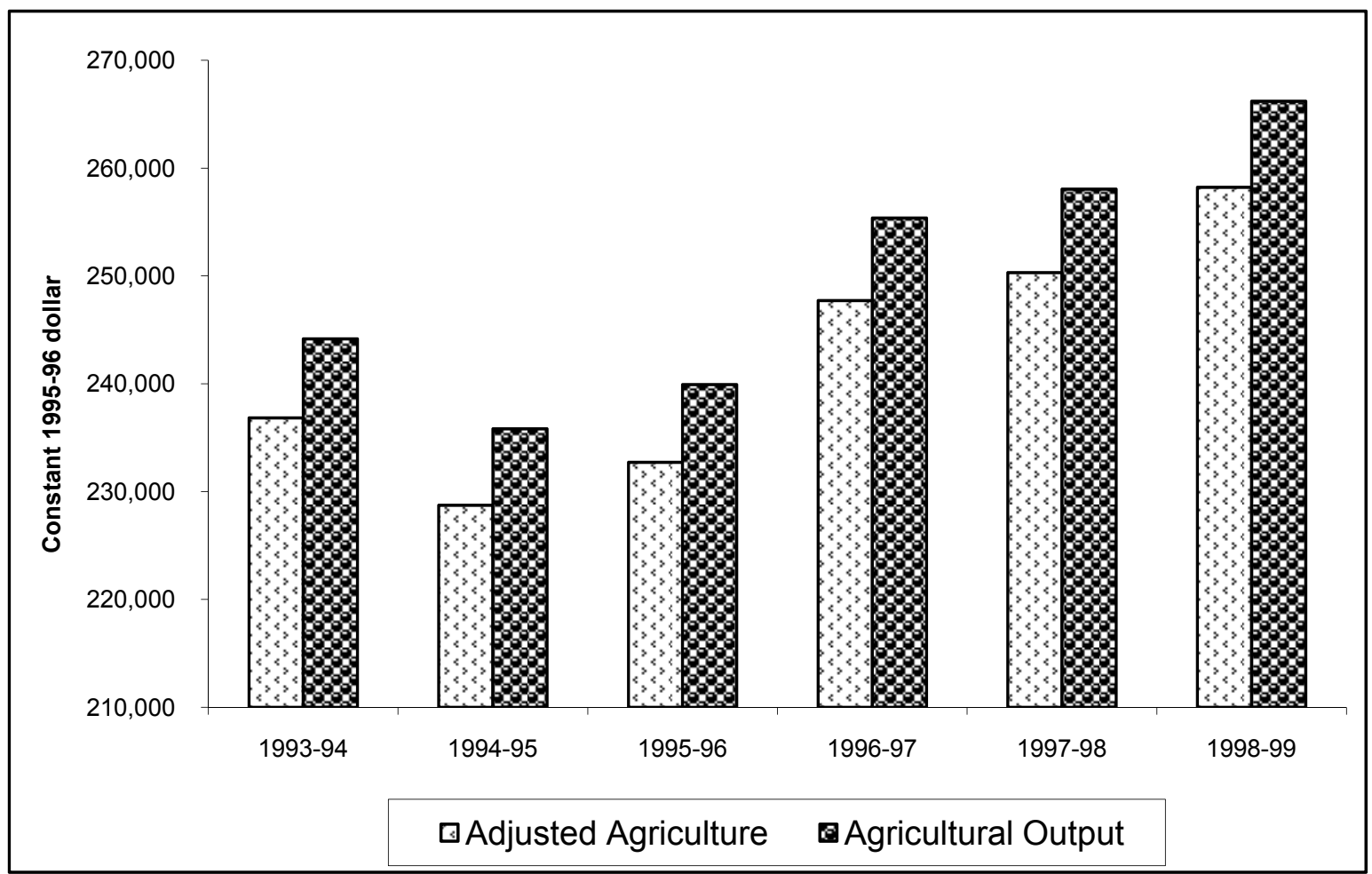

Figure 1. Agricultural product and environmentally adjusted agricultural product of Bangladesh

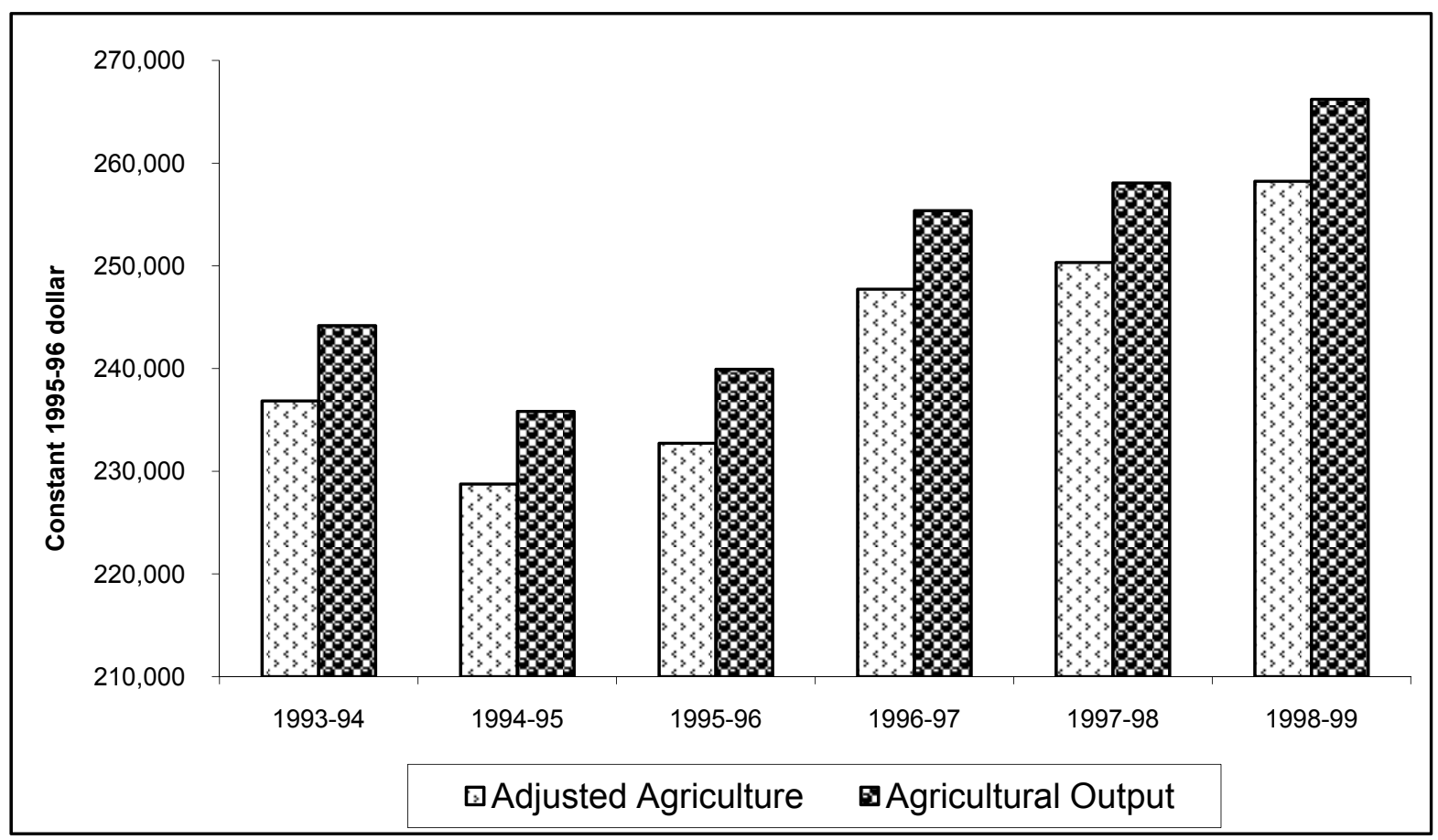

Figure 2. Forest product and environmentally adjusted forest product of Bangladesh 


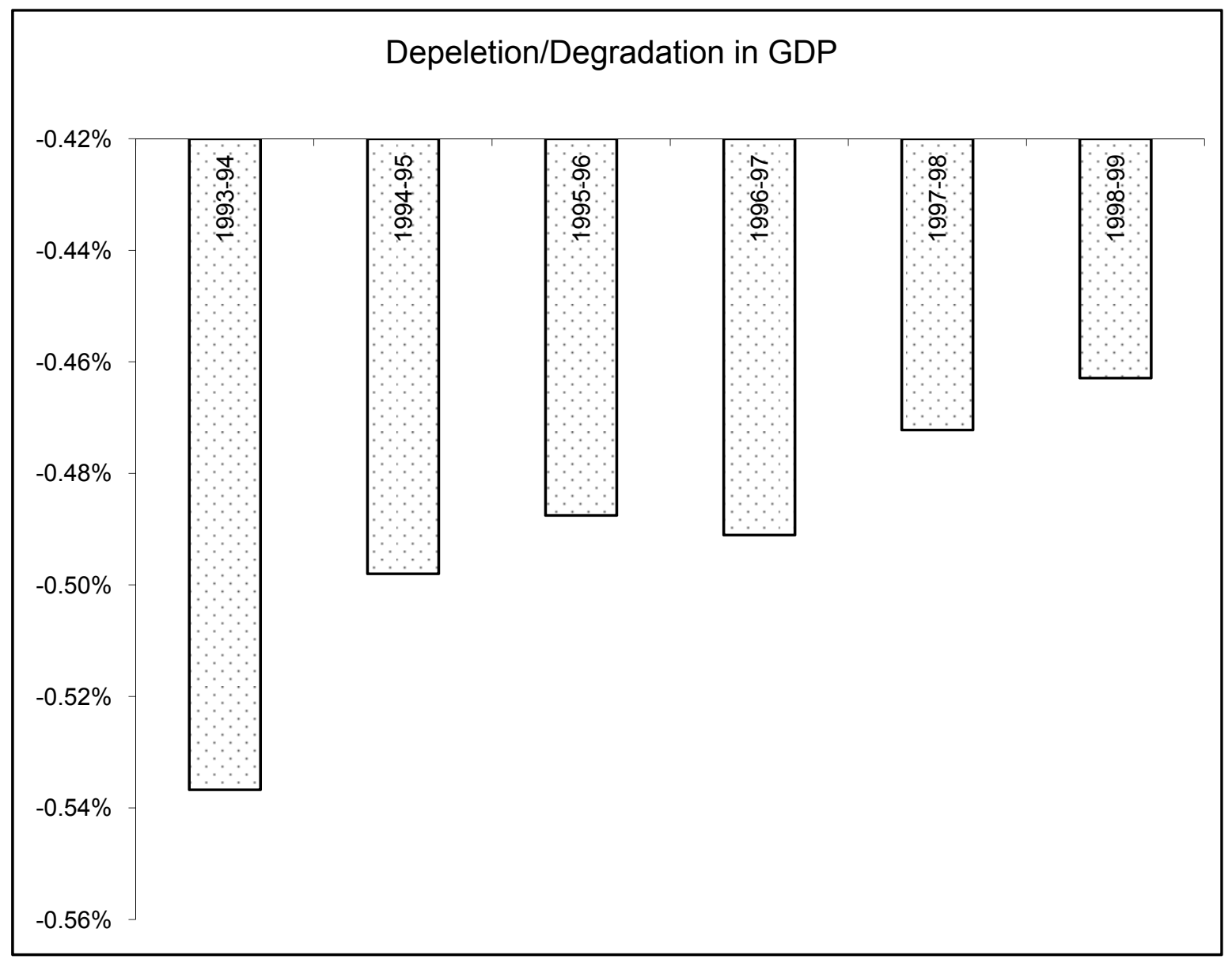

Figure 3. Adjustment to GDP from environmental damage 
Appendix 1. Aggregation of the 79 I-O sectors into the 17 SAM sectors

\begin{tabular}{|c|c|}
\hline Sector & Sector \\
\hline 01. Paddy & 43. Wooden Furniture \\
\hline 02. Wheat & 44. Pulp, Paper \& Board \\
\hline 03. Other Grains & 45. Printing and Publishing \\
\hline 04. Jute & 46. Drugs \& Pharmaceuticals \\
\hline 05. Sugarcane & 47. Fertilizer \\
\hline 06. Potato & 48. Other Chemicals \\
\hline 07. Vegetables & 49. Petroleum Products \\
\hline 08. Pulses & 50. Pottery \& Earthenware \\
\hline 09. Oilseeds & 51. China \& Ceramic \\
\hline 10. Fruits & 52. Glass \& Glass Products \\
\hline 11. Cotton & 53. Bricks, Tiles \& Clay Products \\
\hline 12. Tobacco & 54. Cement \\
\hline 13. Tea & 55. Iron \& Steel Basic Industry \\
\hline 14. Major Spices & 56. Fabricated Metal Products \\
\hline 15. Other Crops & 57. Machinery \\
\hline I. AGRICULTURE & 58. Transport Equipment \\
\hline 16. Livestock & 59. Miscellaneous Industries \\
\hline 17. Poultry & VI. MANUFACTURING \\
\hline II. LIVESTOCK & 66. Electricity \\
\hline 20. Forestry & 67. Gas \\
\hline III. FORESTRY & VII. ELECTRICITY, GAS AND WATER SUPPLY \\
\hline 18. Shrimp & 62. Construction: Electricity \& Gas \\
\hline 19. Other Fish & 63. Construction: Rural Road \\
\hline IV. FISHING & 64. Construction: Other Transport \\
\hline 68. Mining \& Quarrying & 65. Other Construction \\
\hline V. MINING AND QUARRYING & VIII. CONTRUCTION \\
\hline 21. Rice Milling & 69. Trade Service \\
\hline 22. Ata \& Flour Milling & IX. WHOLESALE AND RETAIL TRADE \\
\hline 23. Fish \& Seafood Processing & 77. Hotels \& Restaurants \\
\hline 24. Edible Oil & X. HOTEL AND RESTAURANTS \\
\hline 25. Sugar and Gur & 70. Transport Service \\
\hline 26. Tea (Processing/Blending) & 78. Communications \\
\hline 27. Salt & XI. TRANSPORT, STORAGE \& COMMUNICATION \\
\hline 28. Other Food & 75. Banking \& Insurance \\
\hline 29. Tanning \& Leather Finishing & XII. FINANCIAL INTERMEDIATIONS \\
\hline 30. Leather Products & 60. Urban Building \\
\hline 31. Jute Baling & 61. Rural Building \\
\hline 32. Jute Textile & XIII. REALESTATE \& BUSINESS ACTIVITIES \\
\hline 33. Yarn & 74. Public Administration \& Defence \\
\hline 34. Mill Cloth & XIV. PUBLIC ADMINISTRATION AND DEFENCE \\
\hline 35. Handloom Cloth & 73. Education Service \\
\hline 36. Dyeing \& Bleaching & XV. EDUCATION \\
\hline 37. Readymade Garments & 71. Housing Service \\
\hline 38. Knitting \& Hosiery & 72. Health Service \\
\hline 39. Other Textiles & XVI. HEALTH AND SOCIAL WORK \\
\hline 40. Cigarettes & 76. Professional Services \\
\hline 41. Bidi & 79. Other Services \\
\hline \multirow[t]{2}{*}{ 42. Saw Mills } & XVII. COMMUNITY AND PERSONAL SERVICES \\
\hline & Total \\
\hline
\end{tabular}

